\title{
PENGARUH DISKRIMINASI DAN PEMERIKSAAN PAJAK TERHADAP PERSEPSI WAJIB PAJAK ORANG PRIBADI MENGENAI PENGGELAPAN PAJAK DI KOTA BITUNG (Studi Kasus Pada WPOP yang ditemui di KPP Pratama Bitung)
}

\author{
Prielly Natasya Kartini Widjaja ${ }^{1}$, Linda Lambey ${ }^{2}$, Stanley Kho Walandouw ${ }^{3}$ \\ 1,2,3 Fakultas Ekonomi dan Bisnis. Jurusan Akuntansi. Universitas Sam Ratulangi, Jl. Kampus Bahu, Manado, \\ 95115, Indonesia \\ e-mail: priellynatasya@gmail.com
}

\begin{abstract}
Tax is the highest revenue of the country that. Therefore, government continues to increase the source of revenue derived from taxes. However, in reality there are many taxpayers who do not obey tax laws by evading their taxes. Tax Evasion is a taxpayer's act who always tries to minimize the tax payable by violating the provisions of tax laws. The purpose of this research is to find out the effect of tax discrimination and tax audit of tax evasion. Data were collected by questionnaires. Questionnaires were filled up by 100 tax payers in KPP Pratama Bitung. Technique sampling is non probability sampling with convenience sampling or accidental sampling method. This research used multiple linear regression method and SPSS software version 21.0 was utilized. The result shows tax discrimination has no effect on tax evasion and tax audit influence on tax evasion.
\end{abstract}

Keywords: discrimination, tax audit, tax evasion.

\section{PENDAHULUAN}

Perekonomian suatu negara khususnya negara berkembang tidak dapat dilepaskan dari berbagai kebijakan ekonomi makro yang dilakukan oleh suatu negara. Suatu negara membutuhkan dana untuk membiayai segala kegiatan yang dilakukannya, baik pengeluaran rutin maupun pengeluaran pembangunan dalam menjalankan roda pemerintahan. Salah satu pemasukan terbesar negara adalah dari sektor pajak (Hartono, 2017:1). Menurut UndangUndang Nomor 16 Tahun 2009 Pasal 1 ayat 1 tentang Ketentuan Umum dan Tata Cara Perpajakan, pajak adalah kontribusi wajib kepada negara yang terutang oleh orang pribadi atau badan yang bersifat memaksa berdasarkan undang-undang, dengan tidak mendapatkan imbalan secara langsung dan digunakan untuk keperluan negara bagi sebesar-besarnya kemakmuran rakyat.

Sistem pemungutan pajak merupakan salah satu elemen penting yang menunjang keberhasilan pemungutan pajak suatu negara. Secara umum terdapat tiga sistem pemungutan pajak, yaitu official assessment system, self assessment system, dan withholding system (Mardiasmo, 2016:9). Seiring dengan berjalannya waktu, sejak adanya reformasi di bidang pajak tahun 1983, Indonesia mulai menerapkan self assessment system. Dalam sistem ini, wajib pajak dituntut untuk berperan aktif, mulai dari mendaftar diri sebagai wajib pajak, mengisi SPT, menghitung besarnya pajak yang terutang, dan menyetorkan kewajibannya. (Suminarsasi, 2012:2).

Berbagai cara dilakukan oleh wajib pajak untuk menghindari kewajibannya, baik menggunakan cara yang diperbolehkan oleh undang-undang maupun cara yang melanggar peraturan undang-undang yang berlaku. Cara yang digunakan oleh wajib pajak dengan melanggar dan menentang peraturan undang-undang yang berlaku disebut Tax Evasion yang akan merugikan negara dan tentunya akan dikenakan sanksi administrasi dan pidana bagi pihak-pihak yang melakukan cara tersebut. Penggelapan pajak adalah cara untuk menghindari 
pajak terhutang dengan cara melanggar undang-undang perpajakan atau secara illegal (Masri, 2012:1).

Berdasarkan Undang-Undang No. 39 Tahun 1999 tentang Hak Asasi Manusia Pasal 1 ayat 3, diskriminasi adalah setiap pembatasan, pelecehan, atau pengucilan yang langsung ataupun tak langsung didasarkan pada pembedaan manusia atas dasar agama, suku, ras, etnik, kelompok, golongan, status sosial, status ekonomi, jenis kelamin, bahasa, keyakinan politik, yang berakibat pengurangan, penyimpangan, atau penghapusan pengakuan, pelaksanaan, atau penggunaan hak asasi manusia dan kebebasan dasar dalam kehidupan baik individual maupun kolektif dalam bidang politik, ekonomi, hukum, sosial, budaya dan aspek kehidupan lainnya. Ketika diskriminasi dilakukan oleh aparat pajak, maka akan muncul pola pikir yang buruk kepada aparat pajak, sehingga wajib pajak tergerak untuk melakukan kegiatan penggelapan pajak dan menganggap hal tersebut adalah etis untuk dilakukan.

Salah satu upaya pemerintah dalam menangani kecurangan dalam perpajakan yaitu dengan melaksanakan pemeriksaan pajak, karena pada masa sekarang ini banyak sekali terjadi kecurangan-kecurangan yang dilakukan oleh wajib pajak, diantaranya adalah memanipulasi pendapatan atau penyelewengan dana pajak. Pemeriksaan pajak ini dimaksudkan untuk menguji sejauh mana kepatuhan wajib pajak di dalam pemenuhan kewajiban perpajakannya (Rahman, 2013:11). Definisi pemeriksaan pajak menurut UndangUndang Nomor 28 Tahun 2007 tentang Ketentuan Umum dan Tata Cara Perpajakan adalah serangkaian kegiatan menghimpun dan mengolah data, keterangan dan bukti audit yang dilaksanakan secara objektif dan profesional berdasarkan suatu standar pemeriksaan untuk menguji kepatuhan pemenuhan kewajiban perpajakan dan/atau untuk tujuan lain dalam rangka melaksanakan ketentuan peratura perundang-undangan. Pemeriksaan pajak merupakan bagian vital dari fungsi pengawasan dalam self assessment system, karena tujuan pemeriksaan adalah menguji kebenaran pajak terutang yang dilaporkan wajib pajak berdasarkan data, informasi dan bukti pendukung.

Salah satu instansi terkait yang berperan penting dalam menghimpun pajak pusat masyarakat adalah Kantor Pelayanan Pajak (KPP). KPP berperan penting dalam memberikan pelayanan pajak kepada wajib pajak yang membutuhkan bantuan jika terjadi suatu masalah dalam proses menghitung, menyetor, dan melaporkan pajak terutangnya. Pada penelitian ini, peneliti mengambil objek penelitian di KPP Pratama Bitung. Sampai awal tahun 2017, wajib pajak orang pribadi yang terdaftar di KPP Pratama Bitung sebanyak 31.216 wajib pajak. Tujuan dari penelitian ini adalah untuk mengetahui pengaruh diskriminasi dan pemeriksaan pajak terhadap persepsi wajib pajak orang pribadi mengenai penggelapan pajak di Kantor Pelayanan Pajak di Bitung. Adapun rumusan masalah dalam penelitian ini adalah :

1. Apakah diskriminasi berpengaruh atas persepsi wajib pajak mengenai penggelapan pajak?

2. Apakah pemeriksaan pajak berpengaruh atas persepsi wajib pajak mengenai penggelapan pajak?

3. Apakah diskriminasi dan pemeriksaan pajak berpengaruh atas persepsi wajib pajak mengenai penggelapan pajak ?

\section{TINJAUAN PUSTAKA}

\subsection{Akuntansi}

Menurut Accounting Principles Board dalam Sodikin dan Riyono (2014:1), akuntansi adalah suatu kegiatan jasa. Fungsinya adalah untuk menyediakan informasi kuantitatif, terutama yang bersifat keuangan, tentang entitas ekonomik yang dimaksudkan agar berguna dalam pengambilan keputusan ekonomik-dalam mengambil pilihan-pilihan beralasan di antara pelbagai tindakan alternatif. Menurut Hery (2017:2), akuntansi dapat didefinisikan sebagai sebuah sistem informasi yang memberikan laporan kepada para pengguna informasi 
akuntansi atau kepada pihak-pihak yang memiliki kepentingan (stakeholders) terhadap hasil kinerja dan kondisi keuangan perusahaan.

\subsection{Akuntansi Pajak}

Akuntansi pajak merupakan akuntansi yang berkaitan dengan peraturan perpajakan yang diterapkan oleh pemerintah (Diana dan Lilis,2017:1). Akuntansi pajak membahas peraturan perpajakan serta transaksi akuntansi penting yang berkaitan dengan tujuan menentukan pajak minimum yang dapat dicapai dalam batas-batas yang diperkenankan oleh undang-undang atau peraturan perpajakan (Suwardjono, 2014:39).

\subsection{Teori Dasar Pajak Pengertian Pajak}

Menurut Rochmat Soemitro (Mardiasmo,2016:1), pajak adalah iuran rakyat kepada kas negara berdasarkan undang-undang (yang dapat dipaksakan) dengan tidak mendapat jasa timbal balik (kontrapretasi) yang langsung dapat ditunjukkan dan yang digunakan untuk membayar pengeluaran umum

\section{Fungsi Pajak}

Menurut Mardiasmo (2016:4), ada dua fungsi pajak yaitu:

1. Fungsi Budgetair, yaitu pajak sebagai sumber dana bagi pemerintah untuk membiayai pengeluaran-pengeluarannya.

2. Fungsi Regulerend atau fungsi mengatur, pajak sebagai alat untuk mengatur atau melaksanakan kebijakan pemerintah dalam bidang sosial dan ekonomi.

\section{Sistem Pemungutan Pajak}

Sistem pemungutan pajak menurut Mardiasmo (2016:9), terbagi menjadi 3, yaitu :

1) Official Assesment System

2) Self Assesment System

3) With Holding Tax System

\section{Persepsi}

Menurut Robbins dalam Kurniawati dan Toly (2014:3), persepsi adalah proses dimana seseorang mengatur dan menginterpretasikan kesan-kesan sensoris mereka guna memberikan arti bagi lingkungan. Persepsi wajib pajak mengenai penggelapan pajak adalah cara wajib pajak memandang atau menginterpretasikan suatu peristiwa atau tindakan terkait penggelapan pajak dimana persepsi tersebut dipengaruhi oleh rangsangan fisik (faktor eksternal) dan kecenderungan wajib pajak tersebut (faktor internal).

\section{Diskriminasi}

Menurut Danandjaja dalam Rahman (2013:54), diskriminasi adalah perlakuan yang tidak seimbang terhadap perorangan, atau kelompok, berdasarkan sesuatu, biasanya bersifat kategorikal, atau atribut-atribut khas, seperti berdasarkan ras, kesukubangsaan, agama, atau keanggotaan kelas-kelas sosial. Diskriminasi pajak adalah adanya suatu perlakuan tidak adil yang dilakukan oleh pihak fiskus kepada wajib pajak terhadap perorangan atau kelompok, berdasarkan sesuatu yang biasanya bersifat kategorikal seperti agama, sukubangsa, keyakinan politik atau kelas-kelas sosial yang terkait dengan perpajakan.

\section{Pemeriksaan Pajak}

Menurut Diana Sari (2013:228), pemeriksaan pajak adalah serangkaian kegiatan untuk mencari, mengumpulkan, dan mengelola data dan/atau keterangan lainnya untuk 
menguji kepatuhan pemenuhan kewajiban perpajakan dan untuk tujuan lainnya dalam rangka pemenuhan kewajiban perpajakan berdasarkan ketentuan perundang-undangan perpajakan.

\section{Penggelapan Pajak}

Menurut Diana Sari (2013:54), penggelapan pajak adalah upaya wajib pajak menghindari pajak terhutang secara ilegal dengan cara menyembunyikan keadaan yang sebenarnya. Permita, dkk. (2014:6), mengungkapkan bahwa penggelapan pajak biasa dilakukan perusahaan dengan cara membuat faktur palsu, tidak mencatat penjualan atau laporan keuangan palsu.

\section{Penelitian Terdahulu}

1. Siti Marlina (2014) dengan judul Pengaruh keadilan, Sistem Perpajakan, Diskriminasi, dan Ketepatan Pengalokasian Terhadap Persepsi Wajib Pajak Mengenai Penggelapan Pajak (Tax Evasion) Pada Kantor Pelayanan Pajak Pratama Bintan. Tujuan penelitian untuk menganalisa pengaruh keadilan, sistem perpajakan, diskriminasi dan ketepatan pengalokasian terhadap persepsi wajib pajak mengenai etika penggelapan pajak. Metode yang digunakan Kuantitatif Deskriptif. Hasil penelitian menunjukkan keadilan berpengaruh positif dan signifikan, sistem perpajakan dan diskriminasi tidak berpengaruh dan tidak signifikan dan ketepatan pengalokasian berpengaruh negatif dan signifikan.

2. Raya Puspita Sari Hasibuan (2014) dengan judul Faktor-Faktor Yang Mempengaruhi Persepsi Wajib Pajak Mengenai Etika Penggelapan Pajak (Tax Evasion) (Studi Empiris Di KPP Pratama Medan-Polonia). Tujuan penelitian untuk menganalisa pengaruh intensitas pemeriksaan pajak, keadilan, kepatuhan wajib pajak, pengetahuan wajib pajak, sistem perpajakan, diskriminasi, dan kemungkinan terdeteksinya kecurangan terhadap penggelapan pajak. Metode yang digunakan Kuantitatif Deskriptif. Hasil penelitian menunjukkan intensitas pemeriksaan pajak, kepatuhan wajib pajak, pengetahuan wajib pajak, sistem perpajakan dan kecurangan terhadap penggelapan pajak berpengaruh negatif. Keadilan dan diskriminasi berpengaruh positif terhadap penggelapan pajak.

\section{Hipotesis Penelitian}

Hipotesis merupakan jawaban sementara terhadap rumusan masalah penelitian, oleh karena itu rumusan masalah penelitian biasanya disusun dalam bentuk kalimat. Berdasarkan latar belakang permasalahan yang ada, maka hipotesis dalam penelitian ini adalah :

$\mathrm{Ha}_{1}$ : Diskriminasi berpengaruh terhadap penggelapan pajak.

$\mathrm{Ha}_{2}$ : Pemeriksaan pajak berpengaruh terhadap penggelapan pajak.

\section{METODE PENELITIAN}

\subsection{Jenis Penelitian}

Jenis penelitian ini adalah penelitian deskriptif kuantitatif dengan menggunakan regresi linear berganda. Penelitian deskriptif adalah penelitian yang dilakukan untuk mengetahui dan menjelaskan karakteristik variabel yang diteliti dalam suatu situasi.

\subsection{Tempat dan Waktu Penelitian}

Lokasi penelitian yaitu di KPP Pratama Bitung yang bertempat di jalan Sam Ratulangi, Bitung Barat II, Maesa, Bitung Tengah, Bitung, Kota Bitung, Sulawesi Utara. Penelitian ini dilakukan pada bulan Juni-Juli. 


\subsection{Metode Pengumpulan Data}

\section{Jenis Data}

Jenis data dalam penelitian ini yaitu data kuantitatif yang berupa nilai atau skor atas jawaban yang diberikan oleh responden terhadap pertanyaan-pertanyaan yang terdapat dalam kuesioner.

\section{Sumber Data}

Sumber data yang digunakan dalam penelitian ini adalah data primer yang secara langsung bersumber dari responden tanpa ada perantara, dalam hal ini adalah dari jawaban atas pertanyaan-pertanyaan yang ada dalam kuesioner. Data primer yang dihasilkan dalam penelitian ini adalah merupakan hasi dari tanggapan responden terhadap variabel-variabel penelitian yang akan diuji. Sumber data penelitian ini adalah Wajib Pajak Orang Pribadi (WPOP) yang berada di KPP Pratama Bitung.

\section{Teknik Pengumpulan Data}

1. Penelitian Pustaka (Library Research)

Peneliti memperoleh data yang berkaitan dengan masalah yang sedang diteliti melalui buku, jurnal, internet dan perangkat lain yang berkaitan dengan penggelapan pajak.

2. Penelitian Lapangan (Field Research)

Data utama penelitian ini diperoleh melalui penelitian lapangan, peneliti memperoleh data langsung dari pihak pertama (data primer). Pengumpulan data kuesioner dilakukan dengan teknik personally administered questionnaires, yaitu kuisioner disampaikan dan dikumpulkan langsung oleh peneliti.

\section{Metode Analisis Data}

Metode analisis data yang digunakan dalam penelitian ini adalah analisis regresi linier berganda (Multiple Regression Analysis) dengan bantuan program Statistical Product and Service Solution (SPSS) version 21.0. Analisis ini dimaksudkan untuk mengungkapkan pengaruh antara beberapa variabel bebas yaitu diskriminasi dan pemeriksaan pajak dengan variabel terikat yaitu penggelapan pajak.

\section{Uji Kualitas Data}

\section{Uji Validitas}

Uji validitas digunakan untuk mengukur sah atau valid tidaknya suatu kuesioner. Suatu kuesioner dikatakan valid jika pertanyaan pada kuesioner mampu untuk mengungkapkan sesuatu yang akan diukur oleh kusioner tersebut (Ghozali,2013:52).

\section{Uji Reliabilitas}

Uji reliabilitas ini digunakan untuk menguji konsistensi data dalam jangka waktu tertentu, yaitu untuk mengetahui sejauh mana pengukuran yang digunakan dapat dipercaya atau diandalkan (Ghozali, 2013:48).

\section{Uji Asumsi Klasik}

\section{Uji Normalitas}

Uji Normalitas bertujuan untuk menguji apakah dalam model regresi, variabel dependen dan independen keduanya mempunyai distribusi normal atau tidak. Uji normalitas data dalam penelitian ini menggunakan uji Kolmogorov-Smirnov. Kriteria pengujian dengan menggunakan uji dua arah, yaitu dengan membandingkan 
probabilitas yang diperoleh dengan taraf signifikasi 0.05 . Jika $p$-value $>0.05$ maka data berdistribusi normal (Ghozali, 2013:160).

2. Uji Multikolinieritas

Uji multikolinearitas bertujuan menguji apakah model regresi ditemukan adanya korelasi antar variabel bebas (independen). Model regresi yang baik seharusnya tidak terjadi korelasi di antara variabel independen. Pengujian ini akan dilakukan dengan uji Tolerance dan Variance Inflation Factor (VIF) terhadap setiap variabel independen. (Ghozali, 2013:105).

\section{Uji Heteroskedastisitas}

Uji Heteroskedastisitas bertujuan untuk menguji apakah dalam model regresi terjadi ketidaksamaan variance dari residual satu pengamatan ke satu pengamatan yang lain. (Ghozali, 2013:139).

\section{Uji Regresi Linear Berganda}

\section{Uji Pasial (Uji t)}

Uji t digunakan untuk mengetahui pengaruh variabel independen secara individu (parsial) terhadap variabel dependen.

2. Uji Simultan (Uji F)

Uji $\mathrm{F}$ diperlukan untuk menilai apakah model penelitian layak atau tidak untuk digunakan dan untuk mengetahui pengaruh variabel independen secara bersama-sama (simultan) terhadap variabel dependen.

3. Uji Koefisien Determinasi $\left(\mathbf{R}^{2}\right)$

Uji $\left(R^{2}\right)$ pada intinya mengukur seberapa jauh kemampuan sebuah model menerangkan variasi variabel dependen

\section{HASIL PENELITIAN DAN PEMBAHASAN}

\section{Hasil Uji Asumsi Klasik}

\section{a. Uji Normalitas}

Uji normalitas bertujuan untuk membuktikan bahwa data yang dipergunakan berdistribusi normal. Uji normalitas data yang digunakan adalah uji statistik nonparametrik Kolmogorov-Smirnov (K-S). Apabila angka signifikansi (Sig) $>0.05$ maka data berdistribusi normal. Sebaliknya apabila angka signifikansi kurang dari 0.05 maka data tersebut tidak berdistribusi normal

Tabel 1

One-Sample Kolmogorov-Smirnov Test

\begin{tabular}{|cc|r|}
\hline & & \multicolumn{2}{|c|}{ Unstandardized Residual } \\
\hline \multicolumn{2}{|c|}{$\mathrm{N}$} & 100 \\
Normal Parameters $^{\mathrm{a}, \mathrm{b}}$ & Mean & .0000000 \\
& Std. Deviation & 3.82801863 \\
& Absolute & .089 \\
Most Extreme Differences & Positive & .065 \\
& Negative & -.089 \\
Kolmogorov-Smirnov Z & .894 \\
Asymp. Sig. (2-tailed) & .401 \\
\hline
\end{tabular}

a. Test distribution is Normal.

b. Calculated from data.

Sumber: hasil pengolahan data menggunakan SPSS for windows version 21.0. 
Berdasarkan tabel 4.6, hasil uji normalitas menunjukkan bahwa nilai Kolmogorov-Smirnov untuk persamaan regresi pertama signifikan di atas 0.05 . Hal ini dibuktikan dengan asymp.sig 0.401 lebih besar dari 0.05 , menunjukkan bahwa data telah terdistribusi secara normal.

\section{b. Uji Multikolinieritas}

Uji ini bertujuan untuk menguji apakah dalam model regresi ditemukan adanya korelasi antara variabel-variabel bebas. Dasar pengambilan keputusan, jika nilai tolerance $<0.10$ atau VIF $>10$ maka terjadi multikolinieritas sedangkan jika nilai tolerance $>0.10$ atau VIF $<10$ maka tidak terjadi multikolinieritas.

Tabel 2

\section{Coefficients $^{\mathrm{a}}$}

\begin{tabular}{|c|c|c|c|c|c|c|c|}
\hline \multirow[t]{2}{*}{ Model } & \multicolumn{2}{|c|}{$\begin{array}{c}\text { Unstandardized } \\
\text { Coefficients } \\
\end{array}$} & $\begin{array}{c}\text { Standardized } \\
\text { Coefficients } \\
\end{array}$ & \multirow[t]{2}{*}{$\mathrm{t}$} & \multirow[t]{2}{*}{ Sig. } & \multicolumn{2}{|c|}{$\begin{array}{c}\text { Collinearity } \\
\text { Statistics }\end{array}$} \\
\hline & B & $\begin{array}{l}\text { Std. } \\
\text { Error }\end{array}$ & Beta & & & Tolerance & VIF \\
\hline (Constant) & 17.448 & 1.696 & & 10.286 & .000 & & \\
\hline Diskriminasi & .258 & .176 & .167 & 1.463 & .147 & .629 & 1.590 \\
\hline $\begin{array}{c}\text { Pemeriksaan } \\
\text { Pajak }\end{array}$ & .494 & .169 & .333 & 2.917 & .004 & .629 & 1.590 \\
\hline
\end{tabular}

a. Dependent Variable: Penggelapan Pajak

Sumber: hasil pengolahan data menggunakan SPSS for windows version 21.0.

Berdasarkan tabel 4.7 hasil uji multikolinieritas diatas, maka dapat dilihat bahwa nilai tolerance disetiap variabel independen lebih besar dari 0.10 , begitupun dengan nilai VIF disetiap variabel independen kurang dari $10(<10)$. Dengan demikian, dapat disimpulkan bahwa dalam penelitian ini tidak mengalami multikolinieritas, sehingga salah satu syarat uji regresi berganda telah terpenuhi.

\section{c. Uji Heteroskedastisitas}

Uji Heteroskedastisitas digunakan untuk melihat apakah terdapat ketidaksamaan varians dari residual satu pengamatan ke pengamatan yang lain. Dalam penelitian ini, penulis menggunakan metode scatterplot.

\section{Gambar 1}

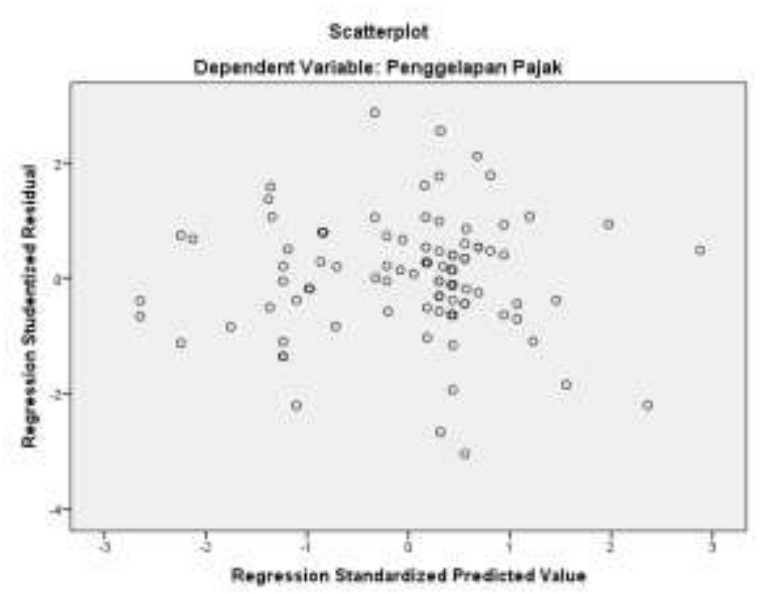

Sumber: hasil pengolahan data menggunakan SPSS for windows version 21.0. 
Dari grafik Scatterplot yang ada pada gambar di atas dapat dilihat bahwa titik - titik menyebar secara acak, serta tersebar baik di atas maupun dibawah angka nol pada sumbu Y. Hal ini dapat disimpulkan bahwa tidak terjadi heteroskedastisitas pada model regresi.

\section{Hasil Uji Regresi Linear Berganda}

\section{a. Hasil Uji Parsial (Uji t)}

Uji t digunakan untuk menguji apakah hipotesis yang diajukan dalam penelitian ini diterima atau tidak dengan mengetahui apakah variabel independen secara individual memengaruhi variabel dependen. Adapun metode dalam penentuan $\mathrm{t}_{\text {tabel }}$ menggunakan ketentuan tingkat signifikan 0,05 .

Tabel 3

Coefficients $^{\mathrm{a}}$

\begin{tabular}{|c|c|c|c|c|c|}
\hline \multirow[t]{2}{*}{ Model } & \multicolumn{2}{|c|}{$\begin{array}{l}\text { Unstandardized } \\
\text { Coefficients }\end{array}$} & $\begin{array}{l}\text { Standardized } \\
\text { Coefficients }\end{array}$ & $\mathrm{t}$ & Sig. \\
\hline & B & Std. Error & Beta & & \\
\hline (Constant) & 17.448 & 1.696 & & 10.286 & .000 \\
\hline Diskriminasi & .258 & .176 & .16 & 1.463 & 147 \\
\hline $\begin{array}{c}\text { Pemeriksaan } \\
\text { Pajak }\end{array}$ & .494 & .169 & .3 & 2.917 & .004 \\
\hline
\end{tabular}

a. Dependent Variable: Penggelapan Pajak

Sumber: hasil pengolahan data menggunakan SPSS for windows version 21.0.

Berdasarkan hasil uji t, dapat disimpulkan sebagai berikut:

a) Pengaruh diskriminasi $\left(\mathrm{X}_{1}\right)$ terhadap penggelapan pajak

Variabel diskriminasi menunjukkan nilai thitung sebesar 1.463 yang mana lebih kecil dari ttabel yakni sebesar 1.988 atau thitung $1.463<$ ttabel 1.988. Selain itu, nilai signifikansi sebesar 0.147 yang mana lebih besar dari 0.05 atau $0.147>0.05$. Hal ini menunjukkan bahwa secara parsial diskriminasi tidak berpengaruh terhadap penggelapan pajak. Jadi hipotesis Ha1 ditolak dan Ho1 diterima.

b) Pengaruh pemeriksaan pajak $\left(\mathrm{X}_{2}\right)$ terhadap penggelapan pajak.

Variabel pemeriksaan pajak menunjukkan nilai thitung sebesar 2.917 yang mana lebih besar dari ttabel yakni sebesar 1.988 atau thitung $2.917>$ ttabel 1.988 . Selain itu, nilai signifikansi sebesar 0.004 yang mana lebih kecil dari 0.05 atau 0.004 $<0.05$. Hal ini menunjukkan bahwa secara parsial pemeriksaan pajak memiliki pengaruh terhadap penggelapan pajak. Jadi hipotesis Ha2 diterima dan Ho2 ditolak.

\section{b. Hasil Uji Simultan ( Uji F)}

Pada penelitian ini, uji F digunakan untuk mengetahui apakah secara simultan koefisien variabel bebas mempunyai pengaruh nyata atau tidak terhadap variabel terikat. Dasar pengambilan keputusannya adalah dengan melihat nilai signifikansi. Apabila nilai sig $<0,05$ atau $F_{\text {hitung }}>F_{\text {tabel }}$ maka terdapat pengaruh variabel $X$ secara simultan terhadap variabel $Y$. Sebaliknya, apabila nilai sig $>0,05$ atau $F_{\text {hitung }}<F_{\text {tabel }}$ maka tidak terdapat pengaruh variabel $\mathrm{X}$ secara simultan terhadap variabel $\mathrm{Y}$. 


\section{Tabel 4}

ANOVA $^{\mathrm{a}}$

\begin{tabular}{|c|c|c|c|c|c|}
\hline Model & Sum of Squares & $\mathrm{df}$ & Mean Square & $\mathrm{F}$ & Sig. \\
\hline Regression & 376.841 & 2 & 188.421 & 12.598 & $.000^{\mathrm{b}}$ \\
\hline 1 Residual & 1450.719 & 97 & 14.956 & & \\
\hline Total & 1827.560 & 99 & & & \\
\hline
\end{tabular}

a. Dependent Variable: Penggelapan Pajak

b. Predictors: (Constant), Pemeriksaan Pajak, Diskriminasi

Sumber: hasil pengolahan data menggunakan SPSS for windows version 21.0.

Hasil analisis menggunakan Fhitung $=12.598>$ Ftabel $=3.09$ dengan tingkat signifikansi adalah $0.000<0.05$, maka dapat disimpulkan bahwa variabel diskriminasi dan pemeriksaan pajak berpengaruh secara simultan terhadap penggelapan pajak.

\section{c. Hasil Uji Koefisien Determinasi $\left(\mathbf{R}^{2}\right)$}

Uji koefisien determinasi (adjusted $R$ square) dilakukan untuk menentukan seberapa besar variabel independen dapat menjelaskan variabel dependen.

\section{Tabel 5}

Model Summary

\begin{tabular}{|c|r|r|r|r|}
\hline Model & R & R Square & $\begin{array}{c}\text { Adjusted R } \\
\text { Square }\end{array}$ & $\begin{array}{c}\text { Std. Error of } \\
\text { the Estimate }\end{array}$ \\
\hline 1 & $.454^{\mathrm{a}}$ & .206 & .190 & 3.86728 \\
\hline
\end{tabular}

a. Predictors: (Constant), Pemeriksaan Pajak, Diskriminasi

Sumber: hasil pengolahan data menggunakan SPSS for windows version 21.0.

Berdasarkan tampilan output model summary pada tabel 4.11 besarnya $\mathrm{R}$ Square adalah 0.206, nilai ini menunjukkan bahwa pengaruh variabel diskriminasi dan pemeriksaan pajak terhadap variabel penggelapan pajak adalah sebesar $20.6 \%$. Sedangkan sisanya $79.4 \%$ dipengaruhi oleh variabel lain yang tidak diteliti dalam penelitian ini.

\section{Pembahasan}

\section{Pengaruh Diskriminasi Terhadap Penggelapan Pajak}

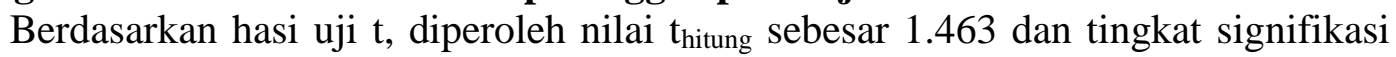
sebesar 0,147. Karena tingkat signifikansi variabel diskriminasi $>0,05(0,147>0,05)$ dan nilai $t_{\text {hitung }}>1,988(1.463>1,988)$. Maka disimpulkan bahwa Ha ditolak dan Ho diterma. Hasil ini menunjukkan bahwa diskriminasi tidak berpengaruh terhadap persepsi wajib pajak mengenai penggepalan pajak.

Hasil penelitian ini konsisten dengan penelitian yang dilakukan oleh Marlina (2014), yang menjelaskan bahwa diskriminasi tidak memiliki pengaruh terhadap penggelapan pajak. Dalam penelitian ini, lebih banyak responden yang menyatakan tidak setuju melakukan penggelapan pajak meskipun telah terjadi praktik diskriminasi dalam perpajakan. Hal ini berarti setinggi apapun tingkat diskriminasi yang dilakukan, penggelapan pajak tetap tidak etis untuk dilakukan. 
Hasil penelitian ini tidak selaras dengan penelitian yang dilakukan oleh Silaen (2015), Ningsih dan Pusposari (2014), dan Suminarsasi (2012), yang menjelaskan bahwa diskriminasi pengaruh terhadap penggelapan pajak. Dengan demikian semakin tinggi tingkat diskriminasi dalam perpajakan maka perilaku penggelapan pajak cenderung dianggap sebagai perilaku etis dan sebaliknya semakin rendah tingkat diskriminasi dalam perpajakan maka perilaku penggelapan pajak cenderung dianggap sebagai perilaku tidak etis.

\section{Pengaruh Pemeriksaan Pajak Terhadap Penggelapan Pajak}

Berdasarkan hasi uji t, diperoleh nilai $t_{\text {hitung }}$ sebesar 2.917 dan tingkat signifikasi sebesar 0,004. Karena tingkat signifikansi variabel diskriminasi $<0,05(0,004<0,05)$ dan nilai $t_{\text {hitung }}>1,988$ ( $\left.2.917>1,988\right)$. Maka disimpulkan bahwa Ha diterima dan Ho ditolak. Hasil ini menunjukkan bahwa pemeriksaan pajak berpengaruh terhadap persepsi wajib pajak mengenai penggepalan pajak.

Hasil penelitian ini konsisten dengan penelitian yang dilakukan oleh Dewi dan Merkusiwati (2016), Ardian dan Dudi Pratomo (2015) dan Hasibuan (2014). Hasil ini dapat disimpulkan bahwa semakin tinggi intensitas pemeriksaan pajak dilakukan maka persepsi wajib pajak akan menilai bahwa perilaku penggelapan pajak merupakan perilaku yang semakin tidak etis untuk dilakukan, begitupun sebaliknya, bila intensitas pemeriksaan pajak semakin rendah maka wajib pajak akan menilai bahwa perilaku penggelapan pajak semakin etis untuk dilakukan. Semakin tinggi intensitas pemeriksaan pajak yang dilakukan oleh fiskus, maka wajib pajak menilai kemungkinan terdeteksinya kecurangan akan semakin tinggi sehingga perilaku penggelapan pajak tidak etis untuk dilakukan.

Dengan demikian, apabila intensitas pemeriksaan pajak semakin sering dilakukan, maka wajib pajak akan semakin enggan untuk melakukan penggelapan pajak. Pemeriksaan pajak dianggap sebagai alat kontrol untuk mendisiplinkan wajib pajak, agar mereka meningkatkan kesadarannya untuk melakukan pembayaran pajak. Pemeriksaan pajak akan memberikan peranan yang lebih baik untuk menghindarkan terjadinya penggelapan pajak. Intensitas pemeriksaan pajak juga menjadi alat evaluasi untuk penerapan undang-undang perpajakan. Dengan demikian, segala tindakan yang tidak baik dalam bidang perpajakan harus dilakukan evaluasi baik bagi pihak pemerintahan maupun pihak wajib pajak.

\section{Pengaruh Diskriminasi dan Pemeriksaan Pajak Terhadap Penggelapan Pajak}

Hasil analisis Uji F diperoleh Fhitung sebesar $12.598>$ Ftabel $=3.09$ dengan tingkat signifikansi adalah $0.000<0.05$. Hasil pengujian ini menunjukkan bahwa variabel diskriminasi dan pemeriksaan pajak berpengaruh secara simultan terhadap penggelapan pajak. Dengan demikian dalam upaya mengurangi penggelapan pajak, pemerintah perlu melakukan perbaikan sistem yang lebih baik lagi dan lebih mempertegas undang-undang perpajakan. Intensitas pemeriksaan pajak yang harus lebih ditingkatkan, menghindarkan kemungkinan terjadinya diskriminasi terhadap wajib pajak dengan cara senantiasa meningkatkan keadilan di bidang perpajakan, serta menerapkan tindakan kontrol yang lebih baik dan lebih tegas untuk mendeteksi kemungkinan terjadinya penggelapan pajak.

\section{KESIMPULAN DAN SARAN}

\section{Kesimpulan}

Berdasarkan hasil penelitian yang telah dilakukan, maka dapat disimpulkan bahwa:

a) Diskriminasi $\left(\mathrm{X}_{1}\right)$ tidak berpengaruh terhadap penggelapan pajak (Y), sehingga hipotesis pertama ditolak. Hal ini mendukung penelitian yang dilakukan oleh Marlina 
(2014). Hasil penelitian ini menunjukkan bahwa setinggi apapun tingkat diskriminasi yang dilakukan, penggelapan pajak tetap tidak etis untuk dilakukan.

b) Pemeriksaan pajak $\left(\mathrm{X}_{2}\right)$ berpengaruh terhadap penggelapan pajak $(\mathrm{Y})$, sehingga hipotesis kedua diterima. Hal ini mendukung penelitian yang dilakukan oleh Dewi dan Merkusiwati (2016) dan Hasibuan (2014). Hasil ini dapat disimpulkan bahwa semakin tinggi intensitas pemeriksaan pajak dilakukan maka wajib pajak akan menilai bahwa perilaku penggelapan pajak merupakan perilaku yang semakin tidak etis untuk dilakukan, begitupun sebaliknya, bila intensitas pemeriksaan pajak semakin rendah maka wajib pajak akan menilai bahwa perilaku penggelapan pajak semakin etis untuk dilakukan.

c) Diskriminasi dan pemeriksaan pajak secara simultan berpengaruh terhadap penggelapan pajak. Dari hasil penelitian ini menunjukkan bahwa keseluruhan variabel Saran diskriminasi dan pemeriksaan pajak mampu mempengaruhi penggelapan pajak.

Berdasarkan simpulan tersebut maka dapat dikemukakan beberapa saran untuk Fiskus/Direktorat Jendral Pajak agar meningkatkan keadilan dalam sistem perpajakan dengan cara mencegah serta menghilangkan segala bentuk diskriminasi dalam perpajakan, dan meningkatkan intensitas pemeriksaan pajak. Bagi wajib pajak disarankan agar lebih aktif mengikuti sosialisasi dan pelatihan yang diadakan oleh DJP serta rutin mengakses website Direktorat Jendral Pajak guna meningkatkan pengetahuan wajib pajak mengenai perpajakan.

\section{DAFTAR PUSTAKA}

Ardian, Raden Devry dan Dudi Pratomo. 2015. Pengaruh Sistem Perpajakan Dan Pemeriksaan Pajak Terhadap Penggelapan Pajak (Tax Evasion) Oleh Wajib Pajak Badan (Studi Pada KPP Pratama Wilayah Kota Bandung). Universitas Telkom Bandung.

Dewi, Ni Komang Trie Julianti dan Ni Ketut Lely Aryani Merkusiwati. 2016. Fakto-faktor Yang Mempengaruhi Persepsi Wajib Pajak Mengenai Etika Atas Penggelapan Pajak( Tax Evasion). Universitas Udayana.

Diana, Anastasia dan Lilis Setiawati. 2017. Akuntansi Keuangan Menengah. Yogyakarta: Penerbit Andi.

Ghozali, Imam. 2013. Aplikasi analisis multivariate dengan program IBM SPSS 21. Edisi Tujuh. Semarang: Universitas Diponegoro.

Hartono, Joana Gladika. 2017. Pengaruh Sistem Pajak, Teknologi Dan Informasi Perpajakan, Serta Etika Uang Terhadap Persepsi Wajib Pajak Mengenai Etika Penggelapan Pajak Dengan Intrinsik Dan Ekstrinsik Religiusitas Serta Gender Sebagai Variabel Moderasi Pada KPP Pratama Taman Sari Satu. Universitas Tarumanegara.

Hasibuan, Raya Puspita Sari. 2014. Faktor-Faktor Yang Mempengaruhi Persepsi Wajib Pajak Mengenai Etika Penggelapan Pajak (Tax Evasion) (Studi Empiris Di Kpp Pratama Medan-Polonia). Universitas Sumatera Utara.

Hery. 2017. Akuntansi Dasar 1 \&2. Jakarta: Penerbit PT Grasindo.

Kurniawati, Meiliana dan Agus Arianto Toly. 2014. Analisis keadilan pajak, biaya kepatuhan, dan tarif pajak terhadap persepsi wajib pajak mengenai penggelapan pajak di Surabaya Barat. Tax and Accounting Review. 4(2). hal. 1-12. Universitas Kristen Petra.

Mardiasmo. 2016. Perpajakan. Edisi Revisi 2016. Jakarta: Penerbit Andi.

Marlina, Siti. 2014. Pengaruh keadilan, sistem perpajakan, diskriminasi, dan ketepatan pengalokasian terhadap persepsi wajib pajak mengenai penggelapan pajak (tax 
evasion) pada Kantor Pelayanan Pajak Pratama Bintan. Kajian Ilmiah. Universitas Raja Hali Aji.

Masri, Indah dan Dwi Martani. 2012. Pengaruh Tax Avoidence Terhadap Cost of Debt. PPJK 20, Tesis Fakultas Ekonomi Universitas Indonesia, Jakarta.

Ningsih, Devi Nur Cahaya dan Devy Pusposari. 2014. Determinan Persepsi Mengenai Etika atas Penggelapan Pajak (Tax Evasion) (Studi Pada Mahasiswa Jurusan Akuntansi Fakultas Ekonomi dan Bisnis Universitas Brawijaya). Universitas Brawijaya.

Permita, Audia Citra, et al. 2014. Pengaruh persepsi wajib pajak orang pribadi atas pelaksanaan self assessment system terhadap tindakan tax evasion di Kota Padang. Simposium Nasional Akuntansi 17. Mataram, Lombok. hal. 1-18. Universitas Mataram.

Rahman, Irma Suryani. 2013. Pengaruh Keadilan, Sistem Perpajakan, Diskriminasi, Dan Kemungkinan Terdeteksinya Kecurangan Terhadap Persepsi Wajib Pajak Mengenai Etika Penggelapan Pajak (Tax Evasion). Universitas Islam Negeri Syarif Hidayatullah.

Sari, Diana. 2013. Konsep Dasar Perpajakan. Bandung: Penerbit PT Refika Aditama.

Silaen, Charles. 2015. Pengaruh sistem perpajakan, teknologi dan informasi perpajakan terhadap persepsi wajib pajak mengenai etika penggelapan pajak. Jom FEKON. 2(2). hal. 1-15. Universitas Riau.

Sodikin, Slamet Sugiri dan Bogat Agus Riyono. 2014. Akuntansi Pengantar 1. Yogyakarta: Penerbit Unit Penerbit Dan Percetakan Sekolah Tinggi Ilmu Manajemen YKPN.

Suminarsasi, Wahyu. 2012. Pengaruh keadilan, sistem perpajakan, dan diskriminasi terhadap persepsi wajib pajak mengenai etika penggelapan pajak (tax evasion). Simposium Nasional Akuntansi 15. Banjarmasin. hal. 1-20. Universitas Gadjah Mada.

Suwardjono. 2014. Akuntansi Pengantar. Yogyakarta: Penerbit BPFE.

Undang-Undang Nomor 16 Tahun 2009 tentang Perubahan Ketiga atas Undang-undang Nomor 6 tahun 1983 tentang Ketentuan Umum dan tata Cara Perpajakan.

Undang-Undang Nomor 28 Tahun 2007 tentang Perubahan Ketiga Atas Undang-undang Nomor 6 Tahun 1983 tentang Ketentuan Umum dan tata Cara Perpajakan.

Undang-Undang Nomor 39 Tahun 1999 tentang Hak Asasi Manusia Pasal 1 ayat 3. 